\title{
Matthias Steup
}

\section{Doxastic Voluntarism and Up-To-Me-Ness}

Rik Peels and I agree on the importance of the concept of epistemic responsibility. We disagree on whether responsibility for our beliefs requires the kind of control needed for responsibility for our actions. I say it does; he says it does not. This disagreement is based on another one: we hold different views on the issue of doxastic voluntarism: Does the kind of control we have over our actions extend to our beliefs? I say it does; he says it does not. I endorse doxastic voluntarism: the view that we have no less control over our beliefs than we have over our actions. He rejects this view. Consequently, we hold different views on how epistemic responsibility is grounded. I claim it is grounded in the same way practical responsibility is: in a kind of control that is direct. Peels claims that epistemic responsibility is grounded instead in indirect influence and in this way crucially differs from the kind of responsibility we bear for our actions.

In his paper "Against Doxastic Compatibilism," Peels has offered two arguments in response to my defense of doxastic voluntarism: the Up-To-Me Argument and the Delay Argument. ${ }^{1}$ In my recent paper "Believing Intentionally," I have explained why I find these arguments unconvincing. ${ }^{2}$ In his excellent book Responsible Belief, Peels defends these two arguments against my criticisms. ${ }^{3}$ I will here continue our debate and respond to his defense of the Up-ToMe Argument. I begin by summarizing why I take doxastic voluntarism to be true.

\section{Intentional Belief}

According to William Alston, belief is akin to digestion and cell metabolism. ${ }^{4}$ Just as there are no causal pathways between our will and digestive processes, there are none between our will and our beliefs. ${ }^{5}$ Consequently, belief is not intentional, just as digestion isn't.

On the face of it, this claim is plausible. Try as you will, you are no more capable of believing that, for example, cats are insects as you are of pausing what's going on in your digestive tract.

\footnotetext{
${ }^{1}$ Peels 2014.

${ }^{2}$ Steup forthcoming.

${ }^{3}$ Peels 2017.

${ }^{4}$ See Alston 1989, p. 122. He says: "Volitions, decisions, or choosings don't hook up with anything in the way of propositional attitude inauguration, just as they don't hook up with the secretion of gastric juices or cell metabolism." For the sake of simplicity, I will use 'belief' to refer to more generally to propositional attitudes such as belief, disbelief, and suspension of judgment.

${ }^{5}$ Let's understand the will to be the capacity to make choices and form intentions.
} 
But upon closer inspection it turns out that Alston is looking at the wrong kind of cases. The cases that he thinks establish his causal disconnection thesis are all cases where what we believe is locked in by powerful evidence, as it is, for example, when you believe it's raining because you see it's raining. ${ }^{6}$ Instead, we should look at cases in which the opportunity for epistemic deliberation arises, that is, cases in which it's initially unclear what propositional attitude your evidence supports. In such cases, you wonder whether you should believe $p$. Suppose you resolve that the evidence for $p$ is stronger than the evidence against $p$. Upon arriving at this conclusion, you start believing $p$. I claim that, when this happens, your belief is intentional. You believe $\mathrm{p}$ because you have decided to believe $\mathrm{p}$. Such cases show that Alston is mistaken: there are causal pathways between our intentions and our beliefs. Since such causal connections exist, belief can be as intentional as actions.

How might one object to this argument? It is well known that

(a) the agent's $\varphi$-ing was caused by the agent's intention to $\varphi$ is not sufficient for

(b) the agent $\varphi$-ed intentionally.

Consider Chisholm's famous example. ${ }^{7}$ A man decides to kill his uncle. On the way to murdering him, the nephew is overwhelmed by nervousness and loses control over his car, accidentally killing a pedestrian. The pedestrian happens to be his uncle. The nephew, then, killed his uncle because he intended to kill him. Nevertheless, the way things turned out, he didn't intentionally kill his uncle. This is an example of deviant causation. In some cases of epistemic deliberation, the subsequently acquired belief might be deviantly caused. But it would be absurd to claim that, in al/ cases of epistemic deliberation, the subsequent beliefs are examples of deviant causation. I do not think, therefore, that the possibility of deviant causation poses a problem for my claim that intentional belief is possible.

Alternatively, it might be argued that, whereas we often conclude an episode of practical deliberation with a decision about what to do, episodes of epistemic deliberation never result in decisions about what to believe. Decisions about what to do are possible, decisions about what to believe are not. I do not think this is a promising strategy. It is entirely unclear why practical and epistemic deliberation should diverge in this way.

\footnotetext{
${ }^{6}$ See Alston 1989, p. 129.

${ }^{7}$ Chisholm 1966, p. 37.
} 
Peels responds to my claim that belief can be intentional with the basic point that a belief's being intentional is not sufficient for it to be under the agent's control. ${ }^{8} \mathrm{I}^{\prime} \mathrm{m}$ happy to agree with that. Whether an action is performed intentionally and whether it was under the agent's control are two different questions. An action may be the result of irresistible compulsion. That doesn't mean it wasn't performed intentionally. Likewise, a belief acquired after deliberation may be, due to irresistible causal forces, beyond the agent's control. That doesn't mean the belief isn't intentional. Lack-of-control arguments do not, therefore, challenge my claim that belief can be intentional.

\section{The Metaphysics of Belief Control}

Alston thought his rejection of doxastic voluntarism had nothing to do with the metaphysics of free will. ${ }^{9}$ Even a philosopher holding an extremely optimistic view about free will is not going to claim that we have control over our digestive processes, for the very reason that the will is causally disconnected from digestion. Since the will is also causally disconnected-obviously so, Alston thought-from belief formation, belief won't be under our control even on the most optimistic view about free will. But, since Alston's causal disconnection thesis is mistaken, he is mistaken as well in thinking that the question of whether doxastic voluntarism is true is not a question of the metaphysics of free will.

If you are a compatibilist, you hold that the world's being entirely deterministic is not an obstacle to acting freely. Free action is not grounded in the absence of causation, but rather in causation of the right kind. For example, actions caused by good practical reasons are free; actions caused by mental illness are not. This formula easily applies to belief. Beliefs caused by good epistemic reasons are free; beliefs rooted in mental illness are not. Peels rejects this argument because, he says, unlike action, belief cannot be intentional. ${ }^{10}$ I claim that belief can be intentional. Therefore, I claim that the argument from missing intentionality fails. If belief can be as intentional as action, then belief is no less within the scope of compatibilist freedom than action is. Hence, if belief can indeed be intentional, then the rejection of doxastic compatibilism requires a general objection: one that targets compatibilism about belief and action alike. An example of such an objection is the well-known Consequence Argument.

\footnotetext{
8 Peels 2017, p. 62ff.

${ }^{9}$ Alston 1989, p. 121.

10 Peels 2017, $76 f$.
} 
Suppose, motivated by either the Consequence Argument or some alternative line of reasoning, you endorse libertarianism. You will then hold that free action requires the absence of causal determination. Of course, you won't hold that nothing is determined. Rather, you will hold that not all events are determined. Some events are undetermined. Under favorable conditions, actions and decisions are undetermined events and can then be free. It is not easy to see why, on such a view, it should be possible for actions, but not for beliefs, to occur without being determined. Libertarianism, just like compatibilism, opens a straightforward path towards doxastic voluntarism.

\section{Up-To-Me-Ness}

Peels doesn't think my way of defending doxastic freedom succeeds because epistemic and practical deliberation differ in the following way:

(D) (i) When I conclude an episode of practical deliberation with a decision to perform a certain action, it is still up to me whether to perform that action. (ii) But when I conclude an episode of epistemic deliberation with a decision to believe $p$, it is not up to me whether to believe . $^{11}$

Two questions arise. First, is (D) true? Second, if (D) is true, what follows? Compatibilists will deny (D). They distinguish between two meanings up-to-me-ness. First, there is up-to-me-ness as libertarians think of it: $\varphi$-ing is at $t$ up to me if, and only if, I can at $t$ decide to $\varphi$ and decide to refrain from $\varphi$-ing. If up-to-me-ness is understood in this way, compatibilists will then reject part (i) of (D) because they take determinism to be true and thus hold that nothing is ever up to me in the libertarian sense of up-to-me-ness. Second, there is up-to-me-ness as compatibilists think of it: $\varphi$-ing is up to me if, and only if, I am embedded in a control-enabling causal nexus. If upto-me-ness is understood in this way, compatibilists need not agree with part (ii) of (D).

(D), then, is safe from rejection only on a libertarian conception of up-to-me-ness. ${ }^{12}$ In "Believing Intentionally," I argued that, if one objects to a compatibilist construal of doxastic voluntarism on the ground that doxastic freedom requires libertarian up-to-me-ness, it is necessary to provide details about how libertarianism is supposed to work. Peels claims that is

\footnotetext{
${ }^{11}$ Peels 2017, p. 62f.

${ }^{12}$ As mentioned above, Alston intended his rejection of doxastic voluntarism to be free of metaphysical presuppositions. That's the ideal strategy for opponents of doxastic voluntarism. Making the rejection of doxastic voluntarism rest on a preference for libertarianism over compatibilism is a deviation from Alston's strategy and significantly weakens the case against doxastic voluntarism. Peels is aware of this and thus intends (D) to be free of commitments regarding the metaphysics of free will. My point is that it isn't.
} 
not necessary. ${ }^{13}$ He seems to think that (D) captures a general datum obvious to everyone, regardless of their view on the metaphysics of free will. But, as I argued above, compatibilists will reject (D). Moreover, as I will argue in the next section, you might want to reject (D) even if you are a libertarian. Before proceeding, however, I'd like to point out what does not follow even if $(D)$ is true. What does not follow is this: when, after deliberating about my reason for and against $p$ I believe $p$ because I resolved that my reasons for $p$ outweigh my reasons against $p$, it's then not the case that I believe $p$ because I decided to believe $p$. That is, it doesn't follow from (D) that belief acquired after epistemic deliberation is not intentional. As I mentioned above, an intentional action need not be one that is up to the agent. Likewise, an intentional belief need not be one that is up to the agent. So, Peels' appeal to up-to-me-ness, whatever its merits may be, does not show that belief cannot be intentional.

\section{Two Types of Up-To-Me-Ness}

Above, I argued that compatibilists will reject (D). Must libertarians accept it? That depends. Let's distinguish between two forms of up-to-me-ness: diachronic and synchronic. Consider the following type of case:

(i) At $t_{1}$, I consider my reasons for and against $\varphi$-ing. I wonder which reasons are stronger. I' $m$ in an indeterministic gap: I can decide to $\varphi$ and I can decide to refrain from $\varphi$-ing. It is up to me what to decide.

(ii) At $t_{2}$ I conclude my deliberation by assigning significantly more weight to the reasons favoring $\varphi$-ing than to my reasons opposing $\varphi$-ing. So, I decide to $\varphi$. I now can no longer decide to refrain from $\varphi$-ing. The transition from $t_{1}$ to $t_{2}$ closes the indeterministic gap that existed at $t_{1}$.

(iii) At $t_{3}$, I perform the action of $\varphi$-ing. I cannot, at $t_{3}$, refrain from $\varphi$-ing.

On the diachronic construal, my $\varphi$-ing at $t_{3}$ is up-to-me because it originated in up-to-me-ness at $t_{1}$. According to the synchronic construal, my $\varphi$-ing at $t_{3}$ is not up to me because at $t_{3}$ I cannot refrain from $\varphi$-ing. The difference between the two types of up-to-me-ness, then, is as follows:

diachronic: a decision or action at $t$ can be up to me because it originated in up-tome-ness prior to $t$, even if at $t \mathrm{I}$ cannot refrain from making that decision or performing that action.

\footnotetext{
${ }^{13}$ Peels, p. $63 f$.
} 
synchronic: a decision or action at $t$ can be up to me only if, at $t$ I can make that decision or perform that action and refrain from making that decision or performing that action.

Libertarians who endorse the diachronic understanding of up-to-me-ness need not agree with part (ii) of (D). Consider:

(i) At $t_{1}$, I consider my reasons for and against believing $p$. I'm in an indeterministic gap: I can decide in favor of and against believing $p$. It is up to me what to decide.

(ii) At $t_{2}$ I conclude my deliberation by assigning significantly more weight to the reasons favoring believing $p$ than to the reasons that oppose believing $p$. I decide to believe $p$. I now can no longer decide against believing $p$.

(iii) At $t_{3}$, I start believing $p$. I cannot refrain from believing $p$.

On the diachronic understanding of up-to-me-ness, my decision at $t_{2}$ and my belief at $t_{3}$ are upto-me because they originate in an indeterministic situation at $t_{1}$ when it was up to me whether to decide in favor of or against believing $p$. Let's consider an example. Upon returning to where I parked my car earlier in the day, I'm baffled to find out it is no longer there. I wonder what to believe: was it towed or stolen? Suppose at this point there is an indeterministic gap: I can decide to believe it was towed and I can decide to believe it was stolen. The decision is up to me. Upon weighing the relevant reasons, I conclude that, on balance, my reasons strongly indicate my car was towed. Now the indeterministic gap is closed: I can longer decide to believe my car was stolen, and I immediately acquire the belief that it was towed. On the diachronic construal, both my belief and my decision were up to me because they originated in an indeterministic gap in which it was up to me what to decide. On the synchronic construal, neither my belief nor my decision were up to me because, when my decision was made and my belief acquired, the indeterministic gap was closed; I could neither decide otherwise nor believe otherwise.

Part (ii) of (D) says: When I conclude an episode of epistemic deliberation with a decision to believe $p$, it is not up to me whether to believe $p$. Libertarians who endorse the diachronic construal of up-to-me-ness will reject this claim. Such libertarians will say that, in the example I described, what to believe-that that my car was stolen or that it was towed-was up to me. 


\section{Libertarianism and Doxastic Control}

I agree with Peels that, on the assumption that libertarianism is true, there is the following interesting difference between practical and epistemic deliberation. ${ }^{14}$ When, in practical deliberation, what's at stake is trivial, or when my reasons are balanced, it can be up to me-in the synchronic sense of libertarian up-to-me-ness-what to decide. For example, if my reasons for and against taking a walk are balanced, I may be in an indeterministic situation in which I can do both: decide to take a walk and decide not to take a walk. In epistemic deliberation, however, balanced reasons do not open an indeterministic gap in which I can both decide in favor of and decide against believing $p$. The reason why they don't is that balanced epistemic reasons dictate suspension of judgment. Peels puts the point thus: "Once I have considered all my reasons, I cannot but suspend judgment on the proposition that the number of stars is even and on the proposition that the coin will turn up heads next time I flip it." ${ }^{\prime 15}$ We have, then, the following difference: if libertarianism is true, then balanced practical reasons allow for an indeterministic gap, balanced epistemic reasons do not. The question is: Is this difference a reason to reject doxastic voluntarism? I do not think it is.

The first thing to note is that the datum in question is not theory-neutral. Compatibilists will reject the claim that, when I consider whether the number of starts is even, it is not up to me which propositional attitude to take. Up-to-me-ness, in the compatibilists sense, is a matter of one's mind being determined by the right kind of causes. In the case at hand, my reasons, being balanced, dictate suspension of judgment. On compatibilism, that just the kind of causation that is control-enabling. Peels rejects doxastic compatibilism because he thinks that belief cannot be intentional. But he hasn't offered an effective response to my claim that belief can be intentional. As I mentioned above, arguments for the conclusion that we lack control over our beliefs fail to show that belief cannot be intentional. So, the number-of-stars example is an example illustrating a lack of doxastic control only if we reject compatibilism on behalf of libertarianism. And the question of whether libertarianism supports the general conclusion that we never enjoy doxastic control cannot be assessed without looking at the details of how libertarianism is supposed to work.

${ }^{14}$ This is, of course, a highly controversial assumption. For a classic worry, see Taylor 1992, p. 48: If, Taylor says, we think of an agent's actions as being undetermined, then "the conception that now emerges is not that of a free person, but of an erratic and jerking phantom, without any rhyme or reason at all."

15 Peels 2017, p. 63. 
Second, when I consider the proposition that the number of stars is even, it is instantly clear that my evidence supports neither belief nor disbelief. There are many cases of epistemic deliberation in which that's different. In such cases, it is initially unclear to me what my evidence supports. Assuming indeterministic gaps exist at all, there is no reason to assume they cannot exist at the outset of cases of this kind. When I am in such an indeterministic gap, it's up to me what to believe. Peels responds by saying that, once I have settled the matter, it is no longer up to me what to believe. But, as I argued above, this conclusion follows only if we work with a rather narrow synchronic construal of libertarian up-to-me-ness. Moreover, his argument leaves unchallenged the claim that, prior to my having settled the matter, it was then up to me what to believe.

Third, libertarianism allows for a rather straightforward type of direct doxastic control. Consider a case of wishful thinking: wanting to go on a bike ride in the afternoon, I believe at $t$, without any evidence, that it's going to be sunny and pleasant. Now, suppose at $t, I^{\prime} m$ in an indeterministic gap regarding the option of considering my evidence. The causal forces acting on me at $t$ allow for both: considering my evidence and not considering my evidence. Suppose if I were to consider my evidence, I would instantly recognize that it doesn't support my belief. At that point, it would no longer be up to me what to believe: I would have to drop my belief and suspend judgment. However, the lack of up-to-me-ness at that point is entirely compatible with up-to-me-ness at $t$ when whether I consider my evidence is not determined. At $t$, it is up to me what to believe because two futures are open to me: one in which I do not consider my evidence and continue believing it's going to be sunny, and another one in which I do consider my evidence and drop the unsupported belief. And clearly, I can be held responsible for my unjustified belief precisely because nothing forces me to have it. To get rid of it, all I need to do is consider my evidence.

I see no reason, then, to concede ground. Arguments from lacking control fail to challenge my claim that belief can be intentional. If belief can be intentional, there is then no special argument against doxastic compatibilism independent of rejecting as well compatibilism about action, and there is then no clear and theory-neutral path from libertarianism to doxastic involuntarism. 


\section{References}

Alston, W. 1989. Epistemic Justification. Essays in the Theory of Knowledge. Ithaca: Cornell University Press.

Chisholm, Roderick. 1966. "Freedom and action." In K. Lehrer (Ed.), Freedom and Determinism. New York: Random House.

Peels, Rik. 2014. "Against Doxastic Compatibilism." Philosophy and Phenomenological Research 89: $679-702$.

Peels, Rik. 2017. Responsible Belief. Oxford: Oxford University Press.

Steup, Matthias. Forthcoming. "Believing Intentionally." Synthese.

Taylor, Richard. 1992. Metaphysics. Upper Saddle River, NJ: Prentice Hall. 